\section{Dragan Momirović ${ }^{1}$}

Visoka poslovna škola za ekonomiju i preduzetništvo

Beograd

\section{Zoran Simonović ${ }^{2}$}

Institute of Agricultural Economics Belgrade
ORIGINAL SCIENTIFIC ARTICLE

DOI: 10.5937/ekonomika2102001P

Received: March, 12. 2021.

Accepted: April, 22. 2021.

\author{
Aleksandar Kostić ${ }^{3}$ \\ University of Pristina - Kosovska Mitrovica, Faculty of Economy
}

\title{
ECB MONETARY POLICY DURING COVID-19
}

\begin{abstract}
This paper aims to point out the monetary policy measures that the European Central Bank has taken since the outbreak of the COVID-19 crisis. In the euro zone, at the start of the COVID-19 crisis, financial conditions deteriorated sharply, potentially threatening to worsen the economic outlook, deepen market fragmentation, jeopardize monetary policy transmission, encourage a downward inflationary trajectory, weaken prices and undermine public and private stability. Aware of the new situation of the ECB, it responded quickly and efficiently with coordinated and ambitious measures to alleviate the perceived financial and economic difficulties. To maintain a flexible monetary policy stance, the ECB adopted an interim non-standard measured COVID-19 Asset Purchase Program (PEPP) to mitigate and improve financial conditions and restart an earlier Asset Purchase Program (APP) aimed at inflation expectations. At the same time, other measures have been strengthened and expanded, such as Targeted Long-Term Refinancing Operations (LTROs, TLTRO III, and PLTRO) aimed at providing liquidity ampleness to the real sector and collateral standards. The implementation of the adopted measures has influenced the stabilization of the economic and financial system of the EU and improved lending to corporate and household banks.
\end{abstract}

Keywords: ECB monetary policy, PEPP COVID-19, LTRO, Securities, financial conditions, financial crisis

JEL classification: G01, E3, E32

\section{МОНЕТАРНА ПОЛИТИКА ЕСВ У ВРЕМЕ ПАНДЕМИЈЕ}

\section{Апстракт}

Циљ овог рада је да укаже на мере монетарне политике које Европска иентрална банка предузела од избијане кризе COVID-19. У еврозони, на старту кризе, дошло је до наглог погориаға финансијских услова који су потенщијално

\footnotetext{
${ }^{1}$ dragomomirovic@gmail.com ORCID ID https://orcid.org/ 0000-0001-9343-9749

${ }^{2}$ zoki@medianis.net, ORCID ID https://orcid.org/0000-0002-2769-6867

3 aleksandar.kostic@pr.ac.rs, ORCID ID https://orcid.org/0000-0002-6315-0765
} 
претили да погориају економске изгледе, продубе фрагментацију тржишта, угрозе пренос монетарне политике, подстакну силазну путању инфлације, ослабе цене и уруше јавну и приватну стабилност. Свесна одговорности ЕСВ је одговорила брзо и ефикасно координираним и амбициозним мерама како би ублажсиле уочене финансијске и економске невоље. Ради подстицаја прилагодљивог става монетарне политике, ЕСВ је усвојила привремену нестандардну меру Пандемијски програм куповине имовине (РЕРР) са циием ублажавања и побољиањ а финансијских услова и поновним покретањем ранијег Програма куповине имовине (АРР) који је усмерен ка инфлационим очекивағима. Истовремено појачане су и проширене друге мере, попут Циљане операџије дугорочног рефинансираға (LTROc, TLTRO III и PLTRO) за обезбеђење ликвидности и релаксаиијом стандарда колатерала. Примена усвојених мера су утищале на стабилизацију економског и финансијског система ЕУ, побољшаюу кредитирања банака предузећа и домаћинства, подстакле узлазу путању инфлаторних очекивања и ублажиле ризике од фрагментације тржишта.

Кључне речи: монетарна политика, ECB, COVID-19, PEPP, LTRO, HoV, финансијски услови, финансијска криза

\section{Introduction}

The outbreak of COVID-19 (further COVID-19) in the European Union (EU) and its rapid spread brought numerous troubles to the health system and threatened to jeopardize the economy. The shock of the COVID-19, in the inceptive phase, caused a health crisis with a large number of infected people and many cases with fatal outcomes. The expansion of the COVID-19 crisis has influenced policymakers in the eurozone to introduce emergency measures, locks to protect the population from this vicious COVID-19. At the same time, vaccination and closure measures have by taken to mitigate and prevent further widening COVID-19s that threatened to turn the health crisis into a financial crisis of unprecedented proportions. Therefore, the EU countries are at the beginning of the COVID-19 crisis faced with two serious challenges. Therefore, the EU countries are at the very beginning of the COVID-19 crisis faced with two serious challenges. The first challenge relates to protecting the health of the population and preserving the health system and the second challenge is connections to maintaining economic and financial stability. The European Central Bank (ECB) was the first in the defense, as many times before, to react to the COVID-19 defense wall. Concerned but not surprised, the ECB responded quickly and creatively to the challenges posed by the expansive of the COVID-19. The ECB encounter three serious challenges: the first to ensure a smooth monetary policy transmission mechanism, the second to mitigate market fragmentation, and the third to slow down the inflation path. Miss Lagarde, Christine, President of the ECB, pointed out that "unlike, in 2008-9, the shock we are facing is universal: it is common both across countries and across all sections of society. Everyone has to scale back their daily activities, and therefore their spending, for as long as the containment measures last. Essentially, for a temporary period, a large part of the economy is being switched off." 


\section{Background}

The intensification of the crisis COVID-19 caused a decline on the supply side, which harmed demand. Such a development has led to a worsening of economic activity, above all, to the tightening of financial conditions. These deteriorations affected the fall in prices, the increase in yields in certain forms of property, and the euro appreciation. During the first two weeks of the crisis, in March, indicators expressing the level of stress in various market segments were very worrying. Financial conditions indices, which summaries our monetary policy stance by considering price movements in equity, bond, foreign exchange, and money markets, signaled an unprecedentedly sharp and abrupt degree of tightening in recent weeks. (Schnabel I, 2020)

Market index the falling value with parallel the increased cost in financing companies, significantly affected the deterioration of financial stability and further deepened the uncertainty, and caused worrying. (Momirović, Bankar, 26) Lagarde, $\mathrm{K}$., says that "the risk-free curve is moving upwards, and the sovereign curves that are important for determining the prices of the entire property have also shifted everywhere and become more distracted." The distinctly negative trend on the financial markets threatened to challenges risks, especially the risk of falling liquidity and many markets the correction of property prices upwards. Potential sources of these threats and unpredictable events would directly jeopardize financial stability and implement monetary policy.

\section{Graph 1.Indicator of systemic stress in financial markets (CISS) (index)}

(0-not stress, 1-high stress)

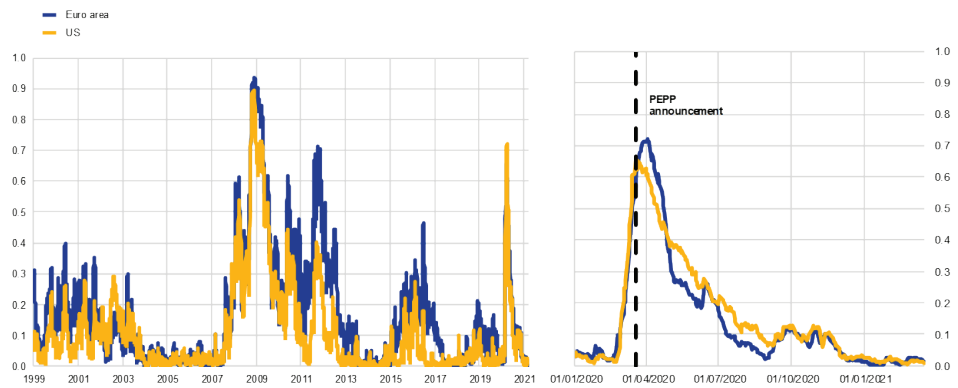

Source: Working Paper Series, No 1426, ECB 2020

The deterioration in financial conditions was most pronounced in the securities market after liquidity dried up. The value of the shares fluctuated within a few weeks of the crisis, only to fall sharply by almost $40 \%$ as government bond yields rose in most countries. The fall in shares the value was a signal for the worrying investors who reoriented themselves and focused on buying property from safe sources. At the same time, in the acutely fragmented eurozone government bond market, there was an abrupt widening in the spread of lower-ranking government bonds. It is that spreads of corporate bonds are showed the levels that were the last during observed the public debt crisis in the eurozone. 
Graph 2. Corporate bond spread (base points)

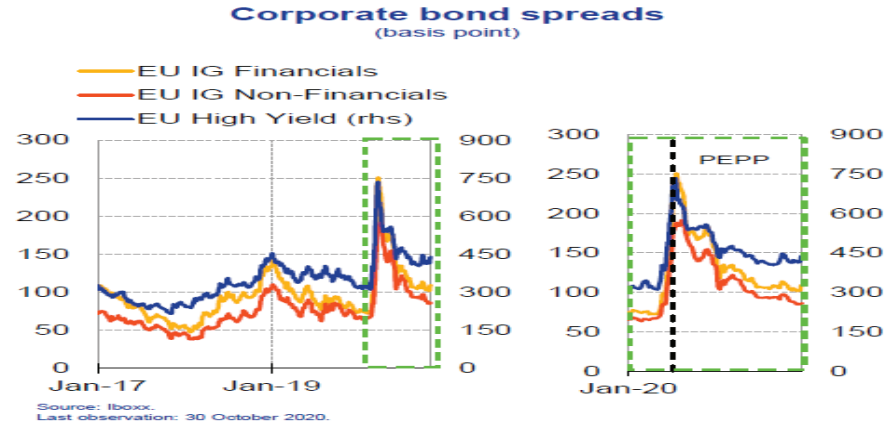

Source: Iboxx, Last observation: 30 October 2020

\section{The ECB's response to the COVID-19}

Aware of its responsibilities, the ECB has dedicated special attention to the choice of measures and policies to respond quickly and efficiently quickly to the difficulties that have befallen the eurozone economy. Worried that the delayed response would deepen and spread the crisis, the ECB reacted quickly, decisively, and creatively to mitigate and ensure that the public health crisis did not spill over into the financial crisis. The ECB has adopted a policy balance to mitigate financial difficulties and maintain the financial system and market money conditions. The ECB's response consists of three carefully selected sets of compatible measures, namely:

1. Pandemic emergency purchase program (PEPP) and new expanded APP,

2. Lending to the real sector (LTRO, s, TLTRO III. PLTRO),

3. Lender of last resort (last resort of liquidity) to solvent banks.

The adopted new and expanded own existing programs had a threefold goal:

1. To ensure that the overall monetary policy stance is sufficiently flexible,

2. Support the stabilization of financial markets to protecting the transmission mechanism of monetary policy,

3. Provide sufficient liquidity, in particular, to maintain current bank lending. (Aguilar, P., Arce, O.,Hurtado, S., Martínez-Martín, Nuño, G., and Thomas, C., 2020)

The essence of the adopted goals is "first to restore the orderly functioning of euro area financial markets, which suffered from an extraordinary degree of volatility, fast de-risking, and thin liquidity conditions. And second to ensure that our accommodative monetary policy continued to be transmitted to all parts of the single currency area, thereby supporting firms and households in shouldering the substantial economic and social costs that this crisis would imply". (Schnabel I, 2020) ECB has adopted measures to effectively contrast the risks in order threaten to jeopardize the transmission mechanism of monetary policy to cushion the blow to the economy, calm inflationary trends, and improve the outlook eurozone.The global financial crisis, caused by the COVID-19 pandemic, is still ongoing, and its finance consequences will be seen only in the years to come. (Gavrilović, Vučeković, 2020) 


\section{COVID-19 emergency purchase program (PEPP) and new expanded APP}

The ECB has adopted a new, unconventional monetary policy measure, the PEPP-a. PEPP is a provisional measure, which started up on March 18, 2020, with an initial envelope of $€ 750 \mathrm{bn}$. From March to June 2020, the widening COVID-19 has affected the deterioration of financial conditions, the decline in economic activity, and the prolongation of the downward trajectory of the inflationary spiral. The ECB responded to this shock on July 4 by increasing the initial PEPP envelope by $€ 600 \mathrm{mn}$ to $€ 1.350 \mathrm{bn}$ to mitigate and prevent further worsening of the financial crisis. In the fourth quarter, 2020, there was a new widening of the Covid-19 and the adoption of new locking measures in many eurozone countries, which threatened to jeopardize the achieved favorable market and financial conditions. The ECB reacted to this occurrence by expanding the PEPP envelope by $€ 500 \mathrm{bn}$ to $€ 1.850 \mathrm{bn}$. Also, the ECB changed the former time interval for the efforts and prolonged the PEPP until 22 March 2022, not excluding the possibility of further extension if the situation so requires. Until the end of 2023, the ECB will continue to manage the PEPP portfolio to conduct a successful monetary policy.

PEPP aims to decrease borrowing costs and increase lending. As expected that purchases by the public sectors within the PEPP-a will be carried out flexibly, with the competence of reference allocations being the capital key of national banks. It will make purchases during a pandemic "flexibly allocated to asset classes and between jurisdictions." (ECB, 2020) The program allows the provisional purchase of property of the same class from the private and public sectors.

Graph 3. Cumulative net purchases of public sector securities - deviation from the capital key in \%

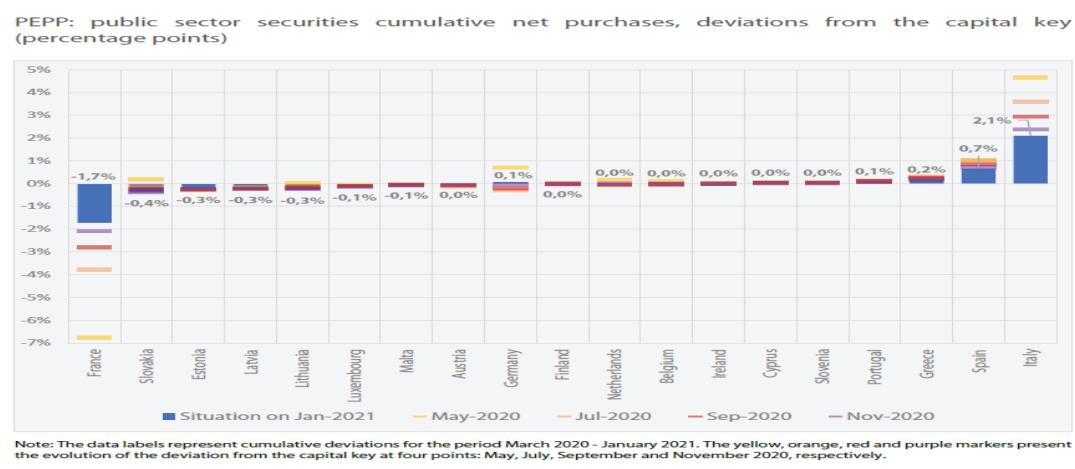

Source: European Parliament (2021) The ECB, s Monetary Policy response to the COVID-19 Crisis

According to the capital key criterion, purchase effectiveness within the PEPP does not show a distinctly and deviation or significant instability. There was a discrepancy in the purchase of bonds through PEPP in Italy and France. It is noticeable that the ECB has made a large purchase of Italian bonds since the launch of the PEPP. The contribution of the capital key of Italy is $17 \%$ and, the purchases conducted of Italian government 
bonds exceed that amount by $4.6 \%$ and amount to $21.6 \%$. In France, the opposite is cases the contribution of bond purchases was below the level of the established capital key. Over time, with progressive adjustment, bond purchase by the eurozone countries achieved at the level of capital keys. Germany's capital key was determined at 26. 4\%, while their contribution in purchases bonds varied from 25 to $27.1 \%$. By was observed that two-month and three-month purchases showed a higher degree of deviation from the established capital keys.

Graph 4. Purchases under PEPP

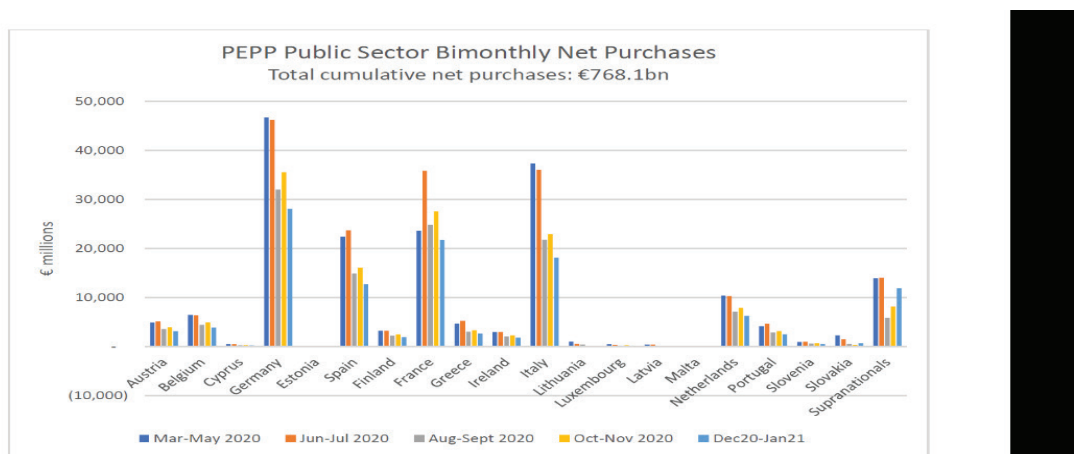

Source Schnabel I., (2021) The ECB's policy response to the COVID-19 pandemic University of Chicago Booth School of Business, 18 February

By the start-up of the PEPP from March 18, 2020, to January 2021, the ECB purchased $€ 810$ bn worth of securities through this program. In the observed period, securities purchases amounted to $60 \%$ of the total targeted program purchases of $€ 1.350$ bn. Available data show that the dynamics of securities purchase realize in January 2021 was the lowest by the stat up of PEPP in March 2020. Within the PEPP, APP purchases were made from March 2020 to January 2021 for $€ 333.2$ bn. All categories of property eligible within the existing APP asset purchase program are also eligible within the PEPP. The new APP has been recalibrated by an additional $€ 120 \mathrm{bn}$, with purchases take place with $€ 20$ bn a month. APP "includes the purchase of euro-denominated bonds issued by euro area-based non-banking corporations." (ICMA, 2021) Also, other programs, within, APP, Covered bond purchase program (CBPPP), and Asset-Backed Securities Purchase Program (ABSPP) and Public Sector Purchase Program (PSPP), and Corporate sector purchase program (CSPP), are acceptable and eligible with PEPP. The ECB has also committed to broadening the range of eligible assets under the existing CSPP to include commercial notice issued by non-financial institutions, making all commercial notice of 'sufficient credit quality' eligible for purchase under the CSPP. Purchases under the CSPP are conducted with counterparties that are eligible for the Eurosystem's monetary policy operations; these are effectively Eurozone banks. (Norton Rose Fulbright, 2020) Monthly net purchases of property under the APP will last as long as necessary to strengthen the adaptive impact of its interest rates that will be complete just before ECB key interest rates begin to rise. The completed reinvestment of principal payments from maturity-backed securities purchased within the APP will continue over a long time by the ECB to raise key interest rates. (National Bank Belgium, 2020) The expanded APP 
aims to purchase a property by the public and private sectors to mitigate and eliminate the risks of too long a period of low inflation, maintain favorable liquidity conditions, and an extensive degree of monetary adjustment.

\section{Graph 6. PEPP Public Sector Bimonthly New Purchase (Total cumulative net purchase EUR 768.1bn}

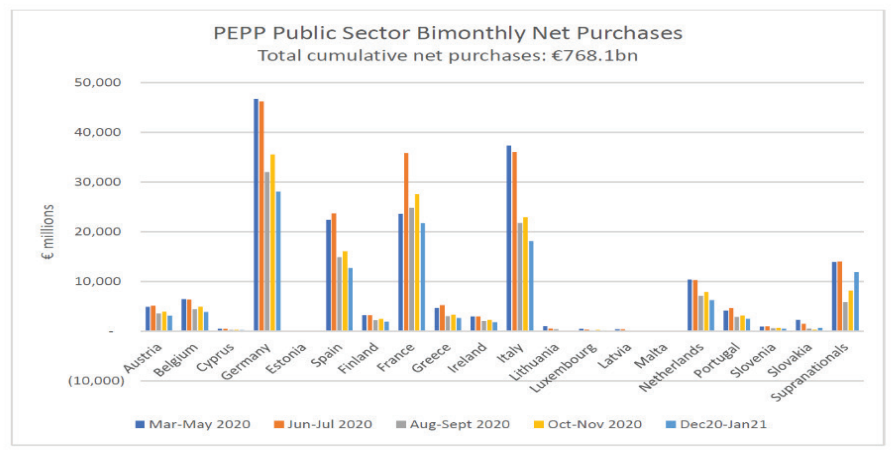

Source: ICMA analysis using ECB data

\section{Source: ICMA}

In the observed period March 2020-January 2021, through PEPP, bonds were purchased by the public sector for $€ 768.1 \mathrm{bn}$. Weekly purchases of public sector bonds were higher at the beginning of the COVID-19 outbreak, with a gradual decline until the end of 2020. The Purchases remained in great measure concentrated in bonds issued by Germany (€ 28.1bn), France (€ 21.8bn), and Italy (€18.1bn). (ICMA 2021)

\section{Graph 7. PEPP Private Sector Holdings (Total EUR 42bn)}

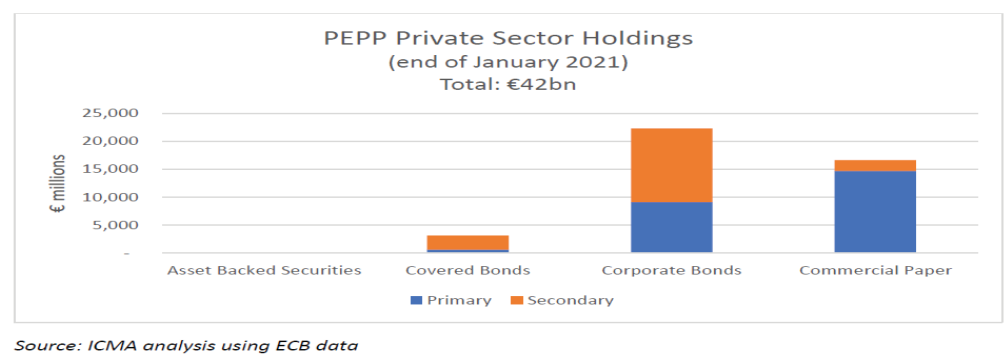

Source: ICMA analysis using ECB data

Source: ICMA analyses using ECB date

In the time, March 2020-2021, within PEPP, securities were purchased by the private sector in the amount of $42 \mathrm{bn}$. In the last quarter of 2020, securities purchases in the private sector recorded a net-negative balance by the end of January 2021 in the structure of PEPP purchases, which amounted to 5\%. 
Graph 8. Cumulative purchases of corporate bonds through PEPP

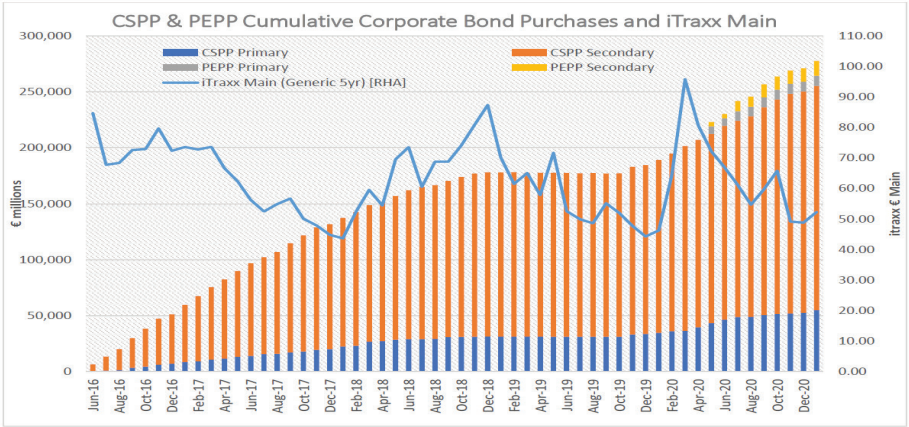

Source: ICMA analysis using ECB and Bloomberg data

Source: ICMA

Purchases under the CSPP dropped off in December 2020 (€2bn) before resuming their usual pace in January 2021 (€4.9bn) 1 This takes total net cumulative purchases under the CSPP to $€ 255.3 \mathrm{bn}$ (of which $€ 54.8 \mathrm{bn}$, or $21 \%$, are primary market purchases, and $€ 200.6 \mathrm{bn}$, or $79 \%$, are secondary). Including the $€ 22.3 \mathrm{bn}$ purchases of corporate bonds under the PEPP, this takes the total net cumulative purchases of corporate bonds to $€ 277.6 b n$. (ICMA, 2021)

\section{Long - term refinancing operations program}

The LTROs operations are expected to be of limited range until June 2020 when they are replaced by the new and expanded TLTRO III. LTRO operations by conducted through a tender procedure with a fixed interest rate which is the same as the average interest rate on deposits. Targeted LTROs operations have the role of supporting the banking sector too, in these irregular conditions, continue to finance and protect the real sector from distress by supplying which is temporarily financing at an interest rate of $0.75 \%$. At the same time, this program should provide an efficient backup in case of need and bridge liquidity in the interval until June 2020. By the outbreak of the COVID-19, the original expanded LTRO operations have provided liquidity to the eurozone financial system (real sector) for $€ 388.9$ bn from March 18 to June 10, 2020. After that, the EU implemented TLTRO III.

TLTRO III is significant for increasing the financial potential and, it will support banks that lend to small and medium enterprises that are most affected by the COVID-19. For that purpose, the volume of financial resources for lending was increased and expanded within TLTRO III by $€ 1.2 \mathrm{bn}$. For more efficient implementation, supply restrictions have by removed to better harmonized participation in operations, and significant incentives for pricing in operations have by added. The sharpening of the crisis in the last quarter of 2020 caused the ECB to extend the initial period of utilization by one year until June 2022. During that period, the ECB decided to conduct three additional TLTRO III operations. Also, the ECB has increased its financial lending potential with the same borrowing conditions to ensure the free flow of credit to the real 
sector. Refinancing interest rates in TLTRO III operations are negative $-1 \%$ and $-0.50 \%$, respectively. In TLTRO III operations, counterparties will borrow financial means from the current $50 \%$ to $55 \%$ of their eligible and eligible loans and available to banks that achieve targeted lending performance. TLTRO III provides liquidity at lower borrowing costs and provides banks sources with advantages of financing, which encourages them to decrease, the issuance of bonds to private markets.

A new PELTRO program was launched by April 30, 2020, adjusted to current market conditions, to conduct seven refinancing operations for time from May to December 2020 and will be ceased by September 2021. The program focuses on supplying liquidity with a fixed interest rate. On December 10, 2021, the ECB broad the scope of PELTRO operations from four new to the existing seven, which should also be closed by 2021.

From the introduction of TRLTO III, by June 2020 to January 2021, completed purchased securities were various for $€ 1.792 \mathrm{bn}$. In the same period, ten TLTRO operations ( 3 TLTRO and 7 PELTRO) will implement, by which only tenders of June 24,2020 , is were in the number of allocated funds for $€ 1.3$ bn by historic. PELTRO's financial operations were conducted, through seven tender procedures, between May 21 and December 3, 2020 with $€ 26.57$ bn allocated.

\section{Conclusion}

A non-standard measure of the ECB's monetary policy, the PEPP has played a double positive role. First, the stabilization of financial markets has been achieved through the flexible purchase of large quantities of securities of classes different in all jurisdictions, thus bypassing the risk of market fragmentation, and second, providing a mechanism for transmission monetary policy to the entire euro area. Large purchases of various securities, through PEPP, provided a large amount of liquidity, which had the effect of mitigating the initial negatives financial conditions caused by the COVID-19. These benefits have helped keep borrowing costs lower in EU countries that use the euro as their currency.

Also, private sector purchases have significantly contributed to easing financial conditions for non-financial corporations (NFCs) and encouraged the revival of the primary market for corporate bond issuance. The spreads of investment bonds NFC and financial sector bonds relative to the risk-free rate remained stable at 59 and 70 basis points, respectively, in January 2021. Overall, there were only minor developments in corporate bonds, with current conditions appearing to be mostly measure based on ongoing fiscal and monetary policy support. (ECB Bulletin 2021)

Annual HICP inflation fell from $1.1 \%$ in the first quarter to $-0.3 \%$ at the end of December 2020. In January and February 2021, annual inflation rose sharply from -0.3 compared to December to $0.9 \%$. The rise in inflation is a consequence of several external circumstances related to the temporary reduction of VAT in Germany, the impact of energy prices on basic inflation, and the jump in oil prices on the world market. Inflation expectations will remain low in the future, even though market indicators of expected inflation are, in a sense, slightly increased. Inflationary expectations by based on mitigated pressure on prices due to weak demand in the tourism and travel sector, low pressures on wage increases, and the appreciation of the euro exchange rate. 
With the introduction of the PEPP, the spread of sovereign yields by stopped, approaching the level before the COVID-19 crisis. Risk premiums in the government bond market are decreases and are close to before the crisis levels. The fall in the costs of companies and households is mitigated the negatives affect the crisis on the economy.

The adoption and implementation of quantitative easing measures (PEPP, TLTRO, and others measure) have led to overcoming uncertainties related to illiquidity, restoring and strengthening confidence, and reducing tensions. These displace have had a direct impact on decreasing the fragmentation of financial markets and raising optimism among participants.

\section{References}

Aßhoff, S., Belke, A., \& Osowski, T. (2021). Unconventional monetary policy and inflation expectations in the Euro area. Economic Modelling, 105564.

Aguilar, P., Arce, O.,Hurtado, S., Martínez-Martín, Nuño, G., and Thomas, C., (2020) The ECB Monetary Policy RESPONSE to the COVID-19 Crisis Banco Espana, Documentos Ocasionales N. ${ }^{\circ}$ 2026, Banco Espana, Eurostat

Baranowski, P., Bennani, H., \& Doryń, W. (2021). Do the ECB's introductory statements help predict monetary policy? Evidence from a tone analysis. European Journal of Political Economy, 66, 1-41.

ECB (2020) Pandemic emergency purchase program, ecb.europa.eu (access 5.4.2020)

Economic Bulletin,(2021) European Central Bank-Europe EU, www ecb.europa.eu (access, 1.4.2021)

European Parliament (2021) The ECB's Monetary Policy response to the COVID-19 Crisis

Gavrilović, K., Vučeković, M., (2020), Impact and Consequences of the COVID -19 VIRUS on the Economy of the United States, International Review No. 3-4, Faculty of Business Economics and Entrepreneurship, Belgrade

Iboxx Last observation: 30 October 2020

ICMA (2021) Corporate bond purchase program

Lagarde C, (2020) Monetary policy in a pandemic emergency www ecb.europa.eu

Momirović, D., (2021) Bankar, Udruženje banaka Crne Gore

National Bank Belgium, (2020) Asset purchase programs, pp. 2

Norton Rose Fulbright, (2020) European Central Bank announces Pandemic Emergency Purchase Programme, pp. 2, United State www. Nortonrosefulbright.com

Rodríguez, C., \& Carrasco, C.A. (2016). ECB policy responses between 2007 and 2014: A chronological analysis and an assessment of their effects. Panoeconomicus, 63(4), 455-473.

Schnabel, I., (2020) The ECB,s response to the COVID-19 pandemic, ECB

Working Paper Series, No 1426, ECB 2020 ecb.europa.eu (access 5.4.2021) 